Bond University

Research Repository

\title{
Do university students, alumni, educators and employers link assessment and graduate employability?
}

Kinash, Shelley; McGillivray, Laura; Crane, Linda

Published in:

Higher Education Research and Development

DOI:

10.1080/07294360.2017.1370439

Licence:

Other

Link to output in Bond University research repository.

Recommended citation(APA):

Kinash, S., McGillivray, L., \& Crane, L. (2018). Do university students, alumni, educators and employers link assessment and graduate employability? Higher Education Research and Development, 37(2), 301-315. https://doi.org/10.1080/07294360.2017.1370439

\section{General rights}

Copyright and moral rights for the publications made accessible in the public portal are retained by the authors and/or other copyright owners and it is a condition of accessing publications that users recognise and abide by the legal requirements associated with these rights.

For more information, or if you believe that this document breaches copyright, please contact the Bond University research repository coordinator. 
Do university students, alumni, educators and employers link assessment and graduate employability?

\section{Shelley Kinash}

Office of Advancement of Learning and Teaching, University of Southern Queensland Toowoomba, Queensland, Australia

E: shelley.kinash@usq.edu.au

\section{Laura McGillivray}

Corresponding author

Faculty of Society \& Design, Bond University

Gold Coast, Queensland, Australia

Email: 1mcgilli@bond.edu.au

\section{Linda Crane}

Faculty of Health Sciences and Medicine, Bond University

Gold Coast, Queensland, Australia

E: 1crane@bond.edu.au 


\title{
Do university students, alumni, educators and employers link assessment and graduate employability?
}

\author{
Shelley Kinash ${ }^{\mathrm{a}}$, Laura McGillivray ${ }^{\mathrm{b}} \&$ Linda Crane $^{\mathrm{c}}$ \\ a Office of Advancement of Learning and Teaching, Toowoomba, Queensland, Australia; \\ b Faculty of Society and Design, Bond University, Gold Coast, Queensland, Australia, \\ c Faculty of Health Sciences and Medicine, Bond University, Gold Coast, Queensland, \\ Australia
}

\begin{abstract}
Within higher education literature, assessment and graduate employability are linked and copresented, in that quality student assessment is purported to enhance employability. This research was designed to query the extent to which these same conceptual links are perceived by those actively involved in higher education. Four stakeholder groups from multiple disciplines and eight Australian states and territories (students, alumni, educators and employers) were interviewed about graduate employability $(n=127)$. Interviewers intentionally omitted any mention of assessment to determine whether the various stakeholders would bring-it-up themselves when asked questions such as what is and is not effective for nurturing employability. The results indicated that among the educators, assessment emerged as a dominant theme. While the three other stakeholder groups infrequently used the term assessment, they did discuss related educational concepts and practices in the context of enhanced employability. All stakeholder groups identified a missing link between theory and practice, with educators specifying that link as assessment. Recommendations to improve employability through assessment are the key takeaways from this research.
\end{abstract}

Keywords: Graduate employability; assessment; stakeholder perspectives; higher education; dissonance

\section{Introduction}

In contemporary higher education, the three concepts of graduate employability, assessment and learning are linked and interwoven (Dahlgren, Reid, Dahlgren, \& Petocz, 2008; Nixon \& Williams, 2014; Regehr, 2013; Smith \& Worsfold, 2015; von Konsky \& Oliver, 2012). Graduate employability is increasingly becoming the why of higher education; the main explicit student motivations for university enrolment are maximised career prospects and earning potential (Arvanitakis, 2014; Brooks \& Everett, 2009; Dahlgren, Reid, Dahlgren, \& Petocz, 2008; Grapragasem, Krishnan, \& Norhaini Mansor, 2014; Haigh \& Clifford, 2011; Taylor \& Hooley, 2014; Thorley, 2014). Assessment is a key how of higher education; educators are increasingly using assessment not only to test students' learning, but as a 
vehicle for learning (Akib \& Najib Adbul Ghafar, 2015; Boud, 2010; Charteris, Quinn, Parkes, Fletcher, \& Reyes, 2016; Hernández, 2012; Kivunja, 2015; Lin, 2016; San, 2016). Learning, therefore, is the what or in other words, the outcome of higher education, meaning that many scholars believe that higher education learning is intended to lead full-circle back to employability (Eaton \& Kleshinski, 2014; Holmes, 2013; Jackson, 2015; Tejaswani \& Madhuri, 2015; Whatley, 2012). Increasingly, texts about graduate employability include chapters on the role of assessment (e.g., Knight \& Yorke, 2004, 2003) and conversely, texts about assessment address the relevance of graduate employability and recommendations for developing assessment that leads to career outcomes (Diamond, 2008; Boud \& Falchikov, 2007; Bryan \& Clegg, 2006; Palomba \& Banta, 1999). Notably, Knight and Yorke (2003) who are world-renowned as employability-scholars, titled their book, Assessment, learning and employability. Throughout the book, they explained the link between the three concepts; for example, writing, 'we need assessment plans to keep track of the diversity that is necessary if assessment is to reach the range of learning intentions that stems from a concern to enhance student employability' (p. 173). Furthermore, Knight and Yorke theorised the intersection between assessment and graduate employability from the perspective of those stakeholders who are most affected - students (and former students), educators and employers.

\section{Graduate employability}

Graduate employability means that 'higher education alumni have developed the capacity to obtain and/or create work' (Kinash et al., 2015b, p. 1). Articulated missions, goals and practices around graduate employability are increasingly prevalent in higher education (Kinash, Crane, Judd \& Knight, 2015c; Bennett, Richardson, \& MacKinnon, 2015; Jollands, et al., 2015). For example, Brown and Carasso (2013) wrote, ‘... as a result of higher charges and a greater emphasis on the economic benefits of higher education, students are switching to more "vocational subjects", whilst institutions are increasing the vocational content or relevance of their courses' (p. 154). Historians conceptualise the always-changing definitional phase-shifts of the university from metaphysical, to research to entrepreneurial and becoming increasingly corporate (Barnett, 2016; Barnett, 2013; Barnett, 2011; Newman, 1982). Such authors cast their literary attention on what it means to be a university and the social and economic implications. One of the resounding debates is whether higher education 'should provide students with competencies currently demanded by the labour market or enhance their innovative potential to enable them to change the economy and the world of 
work' (Grotkowska, Wincenciak, \& Gajderowicz, 2015, p. 870). While graduate employability is the dominant discourse, the literature is replete with debate about whether the purpose/s of higher education are vocational training, career development, economic growth, global competitiveness and/or personal development, knowledge capital, research and critical perspectives (Ashton, 2010; Deakin, 2014; Grotkowska, Wincenciak, \& Gajderowicz, 2015; Holmes, 2013; McArthur, 2011; Thunborg, Bron, \& Edström, 2013; Yang \& Ying Lin, 2014).

Some authors identify graduate employability as part of a neoliberalist agenda (Deakin, 2014; Yang \& Ying Lin, 2014). The neoliberalist argument regarding graduate employability is that it is in the best interests of governments and society for purposes of economic sustainability and growth as well as global competitiveness that a high proportion of the national population attains post-secondary education and graduate employment. However, these goals are constructed and managed as individualistic and commodified whereby the responsibility for paying-for and achieving degrees and graduate employment are offloaded onto families. Furthermore, universities are set-up to resemble a market economy, competing against one-another for student enrolment and thereby tuition and rankings in accordance with employment outcomes. Social critics point to social justice considerations whereby demographic factors reduce the likelihood of some from ever achieving the degrees and career outcomes that are readily available to others, particularly in the context of massification of higher education and thereby credential inflation (Brooks \& Everett, 2009). Furthermore, these critics state that blame is placed on individuals and institutions when failures are actually due to the tail-end of the global financial crisis and over-enrolment in popular degrees/disciplines (Brown \& Carasso, 2013; McArthur, 2011).

\section{Assessment}

Within the context of university responsibility for graduate employability, one of the popular mechanisms articulated by universities is assessment as a means of learning. Assessment can be simply defined as 'the work that students produce to apply their learning and/or demonstrate their subject mastery' (Kinash, 2015a, p. 54). Authors state that there has been a shift in conceptualisation and design of assessment, whereby its former primary use as a vehicle to evaluate students for completion, certification or credentialing has been expanded to also include assessment as a teaching mechanism. In other words, it is now recognised that assessment is of learning and for learning, with the latter thought to be a later and more powerful entry into pedagogy (Akid \& Najib Abdul Ghafar, 2015; Boud, 2010; Charteris, 
Quinn, Parket, Fletcher, \& Reyes, 2016; Hernández, 2012; San, 2016). These authors write that the integral role and function of assessment has become a key feature of the student learning experience. In a seminal text, Brown and Knight (1994) postulated assessment to be the defining feature of education for students because it can drive their behaviour both during and after their higher education learning experience. The primary objective of assessment has shifted from generating classroom competent students to fostering employment-ready graduates (Gulikers, Bastiaens, \& Kirschner, 2004; Lombardi, 2008). Biggs (1996) and Biggs and Tang (2011) proposed that by constructively aligning learning outcomes, teaching, assessment and grading, students would share in a more supportive, responsive and valuable study experience and thereby be better prepared upon graduation. Universities are increasingly being called upon to include assessment outcomes as employability indicators in assurance of quality education (Green, Hammer \& Star, 2009; Kuhn \& Rundle-Thiele, 2009; Treleaven \& Voola, 2008).

\section{Research rationale}

The approach of the remainder of this paper is to describe a research analysis that was conducted to understand the way in which the interaction between graduate employability and assessment are variously articulated by the four key stakeholder groups of undergraduate students, those who have graduated (hereafter called alumni), educators and employers. The key rationale is directly articulated by James (2014) who, in the context of assessment, wrote that one of the most significant problems in higher education is that there is not enough critical thinking, reflective examination and resulting change in pedagogical practices. James said that it is incumbent upon higher education to ask, 'what is happening here in the name of learning' (p. 167). Furthermore, he stated that there is vast diversity between the way in which the various stakeholders experience and interpret these practices.

The secondary rationale for this research is that with the relative newness of the probing of graduate employability stakeholder experiences, assessment practices and their intersection, there is a paucity of empirical literature that collects and collates data on which to inform our understandings. Three separate studies were found that took a similar approach to the research as reported in this paper. Each of these prior studies separately focused on a single stakeholder group. Dahlgren, Reid, Dahlgren and Petocz (2008) queried the student experience to explore the question, "what is the use of higher education in learning for the professions' (p. 145). The researchers conducted a meta-analysis of findings between two large international research projects involving over 500 students in multiple disciplines. 
Assessment either did not emerge, or was not queried, as a research theme. The main finding was that universities appear to over-emphasise a distinction between professions and liberal arts/generalist degrees. Brooks and Everett (2009) focused their inquiry on the experiences of 90 people who had graduated from six different universities in the United Kingdom. Through analysing in-depth life histories, the main finding was that graduates appeared to be realistic and continued to be motivated for further study even if graduate outcomes were not what they had intentioned. Again, either assessment was not directly analysed by the researchers or it did not emerge as a notable theme. Grotkowska, Wincenciak and Gajderowicz (2015) queried managers' perceptions of employability and higher education institutions' activities. They analysed 36 semi-structured interviews in the field of science in six countries. Whereas curriculum formulation emerged as a key adopted employability measure by managers, the researchers only minimally addressed assessment. In relation to the research that has been undertaken and reported to date, the research presented in this article has a distinctive focus: first, on all four stakeholder groups of students, alumni, educators and employers; second, on the combined concepts of graduate employability and assessment and; third, on recommendations regarding how to improve graduate employability through assessment.

\section{Methods and analysis}

As part of a strategic national research project in graduate employability, commissioned by the Australian Government Office for Learning and Teaching, interviews and focus groups were conducted with 127 people (Table One) from four key stakeholder groups - students, alumni, educators and employers (Kinash et al., 2015b). Research participants were from all eight Australian states and territories and from a wide range of disciplines/industries, including examples of psychology, education, accounting and humanities. The overall objective of the project was to consolidate a clearer understanding of graduate employability from the perspective of diverse stakeholders in higher education. This larger study was designed to inform strategies which support and improve graduate outcomes (Kinash et al., $2015 b$ ). As a secondary analysis of the data collected in the larger study, this current study is an extension of this project and aims to offer new and complementary perspectives on the data in the focused space of stakeholder perspectives of assessment and graduate employability. 
Table 1: Interview and Focus Group Participation

\begin{tabular}{ccccc}
\hline Stakeholder & Interviews & Focus Groups & $\begin{array}{c}\text { Focus Group } \\
\text { Participants }\end{array}$ & Total Participants \\
\hline Students & 4 & 5 & 17 & 21 \\
Alumni & 8 & 3 & 18 & 26 \\
Educators & 27 & 12 & 36 & 63 \\
Employers & 17 & - & - & 17 \\
Totals & 56 & 20 & 71 & 127 \\
\hline
\end{tabular}

\section{Methods of primary research}

As the primary dataset of interview and focus group transcripts from Kinash et al. (2015b) were secondarily analysed in this current study, it is necessary to briefly review the original methods. Participants were selected through a combination of convenience sampling (approaching prospective participants at university career fairs) and purposive sampling (using researcher collegial contacts to intentionally recruit). Awareness of the generalisability limitations of these sampling methods was prominent and attempts were made to include a national diversity of institutions, disciplines, employment types and genders through the research (Babbie, 2013). Notably, the research design intentionally included approaches to assure the credibility, transferability, dependability and confirmability of the data and results (Marshall \& Rossman, 2016). The study allowed for deep inquiry into the experiences and perceptions of multiple stakeholder groups, but was not designed for predictive validity (Lincoln \& Guba, 1985). Participant recruitment, data collection, analysis and dissemination adhered to the ethical procedures approved by the lead institution.

Semi-structured interviews and focus groups were intentionally selected as the research approaches (i.e. as opposed to structured surveys) so that participants could tell their own stories, frame their experiences and allow what was personally important to emerge. This inductive approach to the research followed an interpretive qualitative tradition adopted by researchers such as Dahlgren, Reid, Dahlgren and Petocz (2008) and Brooks and Everett (2009), the latter of whom described the research process as intentionally 'allow[ing] respondents to tell their own stories in their own words' and then use subsequent thematic analysis to 'construct general principles about social phenomena' (p. 336). As with Dahlgren et al.'s research, 'the linguistically expressed conceptions of educational issues can be 
understood as related to subjective activities (actual and planned), social (including professional) identities, and cultural and institutional structures' (2008, p. 135).

This qualitative research approach adds a new dimension of inquiry to that typically conducted in the context of employability. Knight and Yorke (2003) wrote that typically, employability research is conducted via surveys whereby respondents are directed to think about and choose whether to select classifications and descriptors that might not represent their experiences or that they might not otherwise have conjured. Dahlgren et al. added a second typical type of employability research described as 'quantitative studies applying preformulated response categories asking the respondent, for example, to agree or disagree with the propositions stated' (2008, p. 134). The semi-structured approach in this qualitative research enabled interviewers to follow and explore emerging themes in participant responses. Examples of questions asked to students, alumni and educators were 'what is good about the graduate employability approaches and supports your university offers/offered' and 'what should be improved about these graduate employability approaches and supports.' Examples of questions to employers were 'to your knowledge, what opportunities did the employee's university provide the students/graduates to enhance their graduate employability,' 'which of these strategies matter to you' and 'which graduate employability strategies and approaches stand out in applications and influence hiring decisions.'

\section{Approach to analysis in secondary research}

The focus of the research reported in this paper was to explore the emergent salience of the topic of assessment in the context of stakeholder conversations about graduate employability. The relationship between assessment and graduate employability was intentionally omitted from the questions asked of the research participants by the researchers in the original research. This allowed the researchers to query whether the various stakeholders would think of and talk about assessment when they were asked questions such as what does and does not work in nurturing employability. In order to investigate whether research participants from each of the stakeholder groups self-introduced assessment as a term and/or concept in their responses to questions about graduate employability, a thematic analysis was conducted on interview and focus group transcripts with the aim of addressing two research questions:

(1) How salient is the theme of assessment (in the context of graduate employability) to students, alumni, employers and educators? 
(2) How do the perspectives on assessment and graduate employability vary between the four stakeholder groups?

Mentions of assessment were included in the frequency count where the use of the term was deemed to fit the operational definition used for this paper 'work that students produce to apply their learning and/or demonstrate their subject mastery' (Kinash, 2015a, p. 54). Terms with synonymous or similar meaning, including the words assignment, examination, test, essay, report and presentation, were also counted at the analysts' discretion. When one of these terms was used, full sentences and/or passages of the research participants' responses were carefully considered to see whether the term assessment could be substituted for the actual vocalised words.

Two types of analysis were conducted - manual and digital. First, using Shaddock's (2014) bottom-up thematic analysis approach, each transcript was analysed manually by physically highlighting content relating to assessment and writing notes of observation and reflection. The data were then methodically organised and catalogued and subsequently coded using the qualitative data analysis software NVivo. The coded material was used to identify patterns across the data, particularly looking for co-occurring themes of graduate employability and assessment. In the qualitative research tradition adopted by researchers such as Dahlgren, Reid, Dahlgren and Petocz (2008), coding noted both within- [stakeholder] group and between-group variation. Prevalent sub-themes, derived verbatim from the transcripts, within the examination of assessment, were also identified and coded throughout the process. These sub-themes were terms which emerged with high frequency alongside text using the term assessment and its synonyms. Subthemes included real world, theory, practice, skills and authenticity.

\section{Results}

Analysis of interview and focus group transcripts revealed that the salience of the theme assessment varied across stakeholder groups, with educators giving the most time and weight to the issue. This distinction was particularly evident when results of the thematic analysis were quantified (see Table Two). Of the overall number of assessment mentions, educators were overwhelmingly (88\%) responsible for them. This finding can in part be explained by the greater number of educators interviewed. However, this heightened salience held-up when analysis considered the within-group responses. More educators spoke about this issue more regularly when compared with other stakeholders. Thirty-five per cent of educators spoke about assessment versus no employers, 29 per cent of students and 19 per cent of 
graduates. Of those educators who spoke about assessment, nine (43\%) made mention five or more (up to 20) times. These results and the range indicate that assessment emerged as a far more prominent issue for educators than for the other groups.

Table 2: Prevalence of the Theme 'Assessment' across Stakeholder Groups

\begin{tabular}{cccccc}
\hline Stakeholder & Participants & $\begin{array}{c}\text { Participants who } \\
\text { mentioned } \\
\text { assessment } \\
\text { (\% of stakeholder } \\
\text { group) }\end{array}$ & $\begin{array}{c}\text { Overall no. of } \\
\text { assessment } \\
\text { mentions } \\
(\% \text { of full data } \\
\text { set })\end{array}$ & $\begin{array}{c}\text { Mean } \\
\text { number of } \\
\text { assessment } \\
\text { mentions by } \\
\text { participant }\end{array}$ & $\begin{array}{c}\text { Range of } \\
\text { assessment } \\
\text { mentions within } \\
\text { stakeholder } \\
\text { groups }\end{array}$ \\
\hline Students & $21(17 \%)$ & $6(29 \%)$ & $11(9 \%)$ & 2 & $1-4$ \\
Alumni & $26(21 \%)$ & $5(19 \%)$ & $5(4 \%)$ & 1 & 1 \\
Educators & $63(50 \%)$ & $22(35 \%)$ & $112(88 \%)$ & 5 & $1-20$ \\
Employers & $17(13 \%)$ & 0 & 0 & 0 & 0 \\
Totals & 127 & 33 & 128 & - & - \\
\hline
\end{tabular}

\section{Students}

While over one quarter of the student participants mentioned assessment, there were an overall low number of mentions across this stakeholder group. Where assessment-related content was mentioned, it was primarily in the context of 'real-world learning.' An undergraduate said, 'when you graduate you want to be able to step out and do your job like straight away, you'll know exactly how to do it.' Later in the interview, this student said, 'I would've thought they'd incorporate [discipline relevant skills] into the learning.' Another student articulated the connection between assessment and employability as a 'missing link.' In another interview, a student said, 'of course theory and knowledge is required, you can't deny that. But how [to] relate that to the real world, that is the question.' This student later said that when assessment is well designed, students can 'really get into it and pull, you know, nuts and bolts out of it and really start distinguishing patterns.' Another student said there should be more 'emphasis on practical skills ... The theory's really important and you have to be able to apply the theory but at the same time it doesn't help you do it [the assignment].' Overall, students emphasised a perception of disconnect between theory and practice in higher education.

\section{Alumni}


In terms of frequency, assessment did not emerge as a salient theme in discussions with participants who had graduated from their degrees; however those who did mention assessment addressed similar themes to those of students. For example, an alumnus highlighted the disparity in experience between assessment and workplace skills, saying that as an employee 'we don't get assessed on ... exams and report writing. Yeah the problem solving and creativity, it's really hard to put into curriculum, but that's what you need in a day-to-day workforce.'

\section{Educators}

Discussions about assessment (in the context of graduate employability) were dominated in interviews and focus groups by educators who largely conveyed a perception that assessment is a fundamental aspect of the student learning experience. One educator suggested that 'when you start thinking about assessment ... that's the big driver ... assessment drives what students do.' Similarly, another educator made the comment, 'assessment drives behaviour, it drives everybody, it drives student behaviour, and it drives academic behaviour. That is why I said assessment is number one, program learning is number two.' An illustrative educator comment was,

The more students who can experience real authentic tasks where theory, education and systematic approaches are brought to bear and they are doing it with students from other disciplines, the more well-rounded and set of tools they are going to get to look at a problem which is great but they will then develop the emotional intelligent skill.

The educator research participants in this study appear to believe that a combined pedagogical focus on assessment and graduate employability has the potential to imbue students with unique, relevant and transferable capabilities which are not born out of 'assessment that just encourages regurgitation.' Another educator participant summarised the potential value of improving the relevance of assessment,

I think we are giving students intellectually demanding tasks, that are integrative and authentic in some way, that required them to engage the literature but apply it to real world problems; they will learn and be able to go into whatever industry.

This educator's call for 'authentic tasks' was explicitly articulated by many of the participants. Another common theme was that assessment design, practices and systems would need to be improved if the impact on graduate employability was to be achieved. An educator said that many academics feel 'a little bit out of touch, in terms of how often we use 
our own assessments.' A number of stakeholders said that the keys to improving assessment and thereby graduate employability are to increase and enhance collaboration with employers. An educator suggested,

Here we are at the university and we've got schools here [pointing in one direction] and we've got employers here [pointing in the opposite direction], we need to extend our circle out just a little bit so we are overlapping.

Similarly, another described a 'need to become the real world or at least have the door swinging both ways a bit more.' Another educator said,

I have had a lot of input from industry. Industry has looked at the assessment and looked at the assignment, given me some help with that and I have talked to a lot of employers about what they want... I am an academic, I am not a careers advisor but at the same time I think I've had a reasonable amount of input to enable me to mark reasonably and appropriately.

An educator emphasised the importance of involving industry to judge student work and offer feedback 'drawn from current practice in industry.' Another used a metaphor to explain that when assessment is judged by field-relevant practitioners, it can be likened to 'a wine connoisseur judging another wine... and then once we get everyone's engagement we start to see better shared views of what's required.'

\section{Employers}

Employers in this study did not directly introduce assessment into conversations about graduate employability. When asked what would improve graduate employability, the majority of employers and educators emphasised the need for 'real world learning' and 'a greater focus on skills.' However, whereas most educators introduced the term and/or concepts of assessment into their dialogue, employers did not. For example, an employer said, 'these days it must be so much of a rude shock of the discord between being trained in what you think you're good at, and to actually practicing it.' In reference to educators, another employer said,

I think they've got a job to let the theory come alive. ... in my day the theory was so boring that it didn't actually go into my brain. And, particularly if we're trying to train future entrepreneurs they're very visual people, they're very tactile people. So straight theory is just not going to cut it.

Overall, it was evident that most of the employers participating in this research believed that it is largely the responsibility of higher education to prepare graduates with career relevant 
skills and many believed that this responsibility was not being met. One employer said that 'rather than focusing on academic content or theory sometimes they should place more emphasis on career preparedness.' Another employer said,

[Students] learn a lot of theory and academic kind of content but is there enough you know, how to manage a project, like actual skills you need when you are working with different individuals at different levels that have different levels of skill.

Another employer said, 'the extent that tertiary education can provide practice in those skills which are fairly bread and butter, it's a really useful thing.' While employers talked about an absence of 'practical learning' they did not articulate assessment as a means of learning the requisite skills.

\section{Discussion}

Just over one quarter of the students participating in this research brought-up assessment when asked about what was and was not working in the context of graduate employability. Of those who did mention assessment, on average, they brought-it-up only twice across the full interview. Dahlgren, Reid, Dahlgren and Petocz (2008) conducted a meta-analysis of research involving 500 students. Their overall research question was, "what is the use of higher education in learning for the professions' (p. 130). Research analysis revealed that while there is disciplinary and professional variation, overall, students tend to see little overlap between university learning and work. They appear to feel that these are two very different life-spaces. The researchers wrote about this phenomenon as 'the variation between students' different ways of experiencing learning and work' (p. 130). This may explain why the students in Dahlgren et al.'s and the research described in this paper did not frequently mention assessment when asked about graduate employability. It appears to be students' implicit belief that assessment is the stuff of education and not the stuff of work.

Only 19 per cent of the participating alumni mentioned assessment and of those who did bring assessment into the conversation about graduate employability; they mentioned it only once throughout the interview. This is consistent with Brooks and Everett's (2009) thematic analysis of 90 university graduate life histories in the UK, in that the authors did not address assessment as a notable theme. Brooks and Everett's overall conclusion was that graduates appeared to be 'informed and realistic about the [tight] labour market' (p. 337). It may be that alumni in the study reported in this paper did not talk about assessment in the context of employability because they do not believe that course-related university work is what makes them employable. This is consistent with the interpretations of Brooks and 
Everett, in that they found that graduates 'believed that to be successful in the labour market it was necessary to consolidate the "basic minimum" of one's first degree with relevant work experience and/or appropriate extra-curricular activities whilst at university' (p. 338). In other words, alumni may not perceive a connection between assessment and employability, regardless of the design and quality.

Overall, 88 per cent of the references to assessment, when asked about graduate employability, were made by academics. This is consistent with prior research. Whereas the two studies described above, the first with students and the second with alumni revealed that these stakeholders did not talk about assessment in the context of employability, the interview content is different in studies of educators. Grotkowska, Wincenciak, and Gajderowicz, (2015) interviewed 36 representatives from seven research institutions in six European countries. Although there was variation among scientific disciplines, the studied educators mentioned assessment activities such as 'group assignments, oral presentations ....and project-based learning elements' as shaping employability (p. 877). Notably, whereas qualitative research in the context of employability was found with students, alumni and educators as research participants, none were found involving employers.

Assessment is clearly an element of education that educators spend a great deal of time on and therefore think about. It is therefore not surprising that assessment was a salient theme in any conversation with educators about education, including in the context of graduate employability. Students also think about assessment, but the frequency analysis indicated that the concept is less salient for them (than for the educators) in the context of graduate employability. This may be because educators are not explicitly linking the two concepts. If educators are not articulating the relevance of assessment to graduate employability, then students are less likely to make the connection. It appears that students perceive assessment as something they do while in university and employment something they do after graduation. The students in this research appear to be highly concerned about developing employability skills, but not many students appear to perceive that assessment may be a primary means by which they can develop these capacities.

Alumni appear to be even further removed from the educational business of assessment. The percentage of alumni who mentioned assessment in the context of graduate employability was 16 points lower than that of educators and the number of assessment mentions overall was 84 per cent different between these two stakeholder groups. Notably, there appears to be low association in the perceptions of graduates between the assessment they did as students and their graduate employability. More notably still, none of the 
employers directly referenced assessment. While educators are concerned with assessment (including in the context of graduate employability) the necessary, and recommended, next step seems to be to communicate and demonstrate that relevance to students, alumni and employers.

\section{Conclusion}

Analysis of interviews and focus groups with students, alumni, educators and employers revealed a range of key findings about participant perceptions of assessment in the context of conversations about graduate employability. Emergent discussions about assessment and associated issues were dominated by educators. Educators spoke about assessment not only more frequently, but typically with more detail and weight. This suggested that educators viewed assessment as a more salient issue and therefore a more instrumental part of graduate employability than did the other higher education stakeholders. The dissonance between the perspectives of the educators and the other stakeholders regarding the connection between assessment and graduate employability points to the need for more explicit articulation. In other words, if it is the intention of educators to assign assessment that advances students' graduate employability and their career identity formation, then this alignment needs to be clearly articulated to students. It is recommended that educators further encourage students to reflect upon the skills they are developing through their assessment that will be relevant to their graduate employability. Furthermore, it is recommended that educators pursue greater collaboration with employers to increase the likelihood of the designed assessment satisfying workplace expectations.

This study aimed to promote a more salient consideration of the potential impact of assessment on graduate employability. The main finding was dissonance between stakeholder groups, in that educators explicitly articulated the link between assessment and graduate employability, whereas students, alumni and employers appeared not to have been apprised of that link. This could mean that educators are not designing assessment that advances graduate employability, that these educators are not explaining this link to the other stakeholders or a combination of both. Recommendations for rectifying this gap, emerging from this study, are increased focus on the design of assessment as well as guided reflection and explicit articulation on the links between assessment, graduate employability and career identity, and finally, the promotion of greater collaboration between employers and universities. 
A strength of this research (in the context of both the primary data collection and secondary analysis) was that in-depth interviews were held with multiple stakeholder groups thereby contributing to rich experiential perspectives on the link between employability and assessment. A second strength was that assessment was not researcher-introduced into the study so that analysis could reveal whether students, alumni, educators and employers would bring-up this topic themselves. A limitation was the discrepant size of the stakeholder groups and most notably, the substantially larger size of the educator group as compared to other groups. This was based on the willingness of various stakeholders to participate in the research. It is suggested that future research approaches focus on increasing the size of the other participant groups. Furthermore, now that this secondary analysis has identified the disparate salience of assessment to various stakeholder groups, primary research is recommended to follow-up and directly probe the relationship between assessment and graduate employability.

\section{Acknowledgement}

The views expressed in this paper do not necessarily reflect the views of the Australian Government Office for Learning and Teaching.

\section{Disclosure statement}

No potential conflict of interest.

\section{Funding}

This work was supported by the Australian Government Office for Learning and Teaching [grant number SP13-3239].

\section{References}

Akib, E., \& Najib Abdul Ghafar, M. (2015). Assessment for learning instrumentation in higher education. International Education Studies, 8(4), 166-172. doi:10.5539/ies.v8n4p166

Arvanitakis, J. (2014). Massification and the large lecture theatre: From panic to excitement. Higher Education, 67, 735-745. doi:10.1007/s10734-013-9676-y

Ashton, D. (2010). Productive passions and everyday pedagogies: Exploring the industry-ready agenda in higher education. Art, Design \& Communication in Higher Education, 9(1), 41-56. doi:10.1386/adch.9.1.41_1

Babbie, E. (2013). Social research counts. Belmont, CA : Wadsworth: Cengage Learning.

Barnett, R. (2011). Being a university. London: Routledge.

Barnett, R. (2013). Imagining the university. London: Routledge.

Barnett, R. (2016). Understanding the university: Institution, idea, possibilities. London: Routledge. 
Bennett, D., Richardson, S., \& MacKinnon, P. (2015). Enacting strategies for graduate employability: How universities can best support students to develop generic skills: Final report 2015. Sydney: Australian Government Office for Learning and Teaching

Biggs, J. (1996). Enhancing teaching through constructive alignment. Higher Education, 32, 347-364. Biggs, J., \& Tang, C. (2011). Teaching for quality learning at university (4th ed.). Maidenhead, UK: McGraw Hill Education \& Open University Press.

Boud, D. (2010). Assessment 2020: Seven Propositions for Assessment Reform in Higher Education. Sydney: Australian Learning and Teaching Council.

Boud, D., \& Falchikov, N. (Eds.). (2007). Rethinking assessment in higher education: Learning for the longer term. Oxon: Routledge.

Brooks, R., \& Everett, G. (2009). Post-graduation reflections on the value of a degree. British Educational Research Journal, 35(3), 333-349. doi:10.1080/01411920802044370

Brown, S., \& Knight, P. (1994). Assessing learners in higher education. London: Kogan Page.

Brown, R., \& Carasso, H. (2013). Everything for sale? The marketisation of UK higher education. London: Routledge.

Bryan, C., \& Clegg, K. (Eds.). (2006). Innovative assessment in higher education. Oxon: Routledge. Charteris, J., Quinn, F., Parkes, M., Fletcher, P., \& Reyes, V. (2016). e-Assessment for learning and performativity in higher education: A case for existential learning. Australasian Journal of Educational Technology, 32(3), 112-122.

Dahlgren, M.A., Reid, A., Dahlgren, L.W., \& Petocz, P. (2008). Learning for the professions: Lessons from linking international research projects. Higher Education, 56, 129-148. doi:10.1007/s10734-007-9094-0

Deakin, H. (2014). The drivers to Erasmus work placement mobility for UK students. Children's Geographies, 12(1), 25-39. doi:10.1080/14733285.2013.851063

Diamond, R. M. (2008). Designing and assessing courses and curricula: a practical guide (3rd ed.). San Francisco: Jossey-Bass.

Eaton, T.V., \& Kleshinski, A.S. (2014). Improving undergraduate learning for employability through international exposure. American Journal of Business Education, 7(1), 49-57.

Grapragasem, S., Krishnan, A., \& Norhaini Mansor, A. (2014). Current trends in Malaysian higher education and the effect on education policy and practice: An overview. International Journal of Higher Education, 3(1), 85-93. doi:10.5430/ijhe.v3n1p85

Green, W., Hammer, S., \& Star, C. (2009). Facing up to the challenge: Why is it so hard to develop graduate attributes? Higher Education Research \& Development, 28(1), 17-29. doi:10.1080/07294360802444339

Grotkowska, G., Wincenciak, L., \& Gajderowicz, T. (2015). Ivory-tower or market-oriented enterprise: The role of higher education institutions in shaping graduate employability in the 
domain of science. Higher Education Research \& Development, 34(5), 869-882L

doi:10.1080/0729360.2015.1011090

Gulikers, J. T., Bastiaens, T. J., \& Kirschner, P. A. (2004). A five-dimensional framework for authentic assessment. Education Technology Research \& Development, 52(3), 67-86. doi:10.1007/BF02504676

Haigh, M., \& Clifford, V.A. (2011). Integral vision: a multi-perspective approach to the recognition of graduate attributes. Higher Education Research \& Development, 30(5), 573-584. doi:10.1080/07294360.2011.598448

Hernández, R. (2012). Does continuous assessment in higher education support student learning? Higher Education, 64, 489-502. doi:10.1007/s10734-012-9506-7

Holmes, L. (2013). Competing perspectives on graduate employability: Possession, position or process? Studies in Higher Education, 38(4), 538-554. doi:10.1080/03075079.2011.587140

Jackson, D. (2015). Employability skill development in work-integrated learning: Barriers and best practice. Studies in Higher Education, 40(2), 350-367. doi:10.1080/03075079.2013.842221

James, D. (2014). Investigating the curriculum through assessment practice in higher education: The value of a 'learning cultures' approach. Higher Education, 67, 155-169. doi:10.1007/s10734013-9652-6

Jollands, M., Clarke, B., Grando, D., Hamilton, M., Smith, J., Xenos, S., Carbone, A.; Burton, L.; Brodie, M.; \& Pocknee, C. (2015). Developing graduate employability through partnerships with industry and professional associations. Sydney, Australia: Australian Government Office for Learning and Teaching.

Kinash, S. (2015a). Using education technology in simple ways to improve assessment. Education Technology Solutions, 67, 52-55. Retrieved from http://www.educationtechnologysolutions.com.au/2015/12/using-education-technology-insimple-ways-to-improve-assessment/

Kinash, S., Crane, L., Judd, M.-M., Mitchell, K., McLean, M., Knight, C., Dowling, D. \& Schulz, M. (2015b). Supporting graduate employability from generalist disciplines through employer and private institution collaboration. Report prepared for the Office for Learning and Teaching, Australian Government.

Kinash, S., Crane, L., Judd, M.M., Knight, C. (2015c). Discrepant stakeholder perspectives on graduate employability strategies. Higher Education Research \& Development, 35(5), 951967. doi: 10.1080/07294360.2016.1139555

Kivunja, C. (2015). Innovative methodologies for $21^{\text {st }}$ century learning, teaching and assessment: A convenience sampling investigation into the use of social media technologies in higher education. International Journal of Higher Education, 4(2), 1-26. doi:10.5430/ijhe.v4n2p1

Knight, P., \& Yorke, M. (2003). Assessment, learning and employability. London: Open University Press. 
Knight, P., \& Yorke, M. (2004). Learning, curriculum and employability in higher education. London: Routledge.

Kuhn, K. L., \& Rundle-Thiele, S. R. (2009). Curriculum alignment: Exploring student perception of learning achievement measures. International Journal of Teaching and Learning in Higher Education, 21(3), 351-361.

Lin, G-Y. (2016). Effects that Facebook-based online peer assessment with micro-teaching videos can have on attitudes toward peer assessment and perceived learning from peer assessment. Eurasia Journal of Mathematics, Science \& Technology Education, 12(9), 2295-2307. doi:10.12973/Eurasia.2016.1280a

Lincoln, Y. S., \& Guba, E. G. (1985). Naturalistic inquiry. Newbury Park, CA: Sage Publications. Lombardi, M. (2008). Making the grade: The role of assessment in authentic learning. Retrieved July 2015, from Educause Learning Initiative: http://net.educause.edu/ir/library/pdf/ELI3019.pdf

Marshall, C., \& Rossman, G. B. (2016). Designing qualitative research (6th ed.). Los Angeles, CA: Sage.

McArthur, J. (2011). Reconsidering the social and economic purposes of higher education. Higher Education Research \& Development, 30(6), 737-749. doi:10.1080/072944360.2010.539596

Newman, J.H. (1982). The idea of a university. Notre Dame, IN, USA: Notre Dame University.

Nixon, S., \& Williams, L. (2014). Increasing student engagement through curriculum redesign: Deconstructing the 'apprentice' style of delivery. Innovations in Education and Teaching International, 51(1), 26-33. doi:10.1080/14703297.2013.845535

Palomba, C. A., \& Banta, T. W. (1999). Assessment essentials: planning, implementing and improving assessment in higher education (3rd ed.). San Francisco: Jossey-Bass.

Regehr, C. (2013). Trends in higher education in Canada and implications for social work education. Social Work Education, 32(6), 700-714. doi:10.1080/02615479.2013.785798

San, I. (2016). Assessment for learning: Turkey case. Universal Journal of Educational Research, 4(1), 137-143. doi:10.13189/ujer.2016.040117

Shaddock, A. (2014). Using data to improve learning: A practical guide for busy teachers. Melbourne, VIC: ACER.

Smith, C., \& Worsfold, K. (2015). Unpacking the learning-work nexus: 'Priming' as lever for highquality learning outcomes in work-integrated learning curricula. Studies in Higher Education, 40(1), 22-42. doi:10.1080/03075079.2013.806456

Taylor, A.R., \& Hooley, T. (2014). Evaluating the impact of career management skills module and internship programme within a university business school. British Journal of Guidance \& Counselling, 42(5), 487-499. doi:10.1080/03069885.2014.918934

Tejaswani, K., \& Madhuri, G.V. (2015). Designing transferable skills inventory for assessing students using group discussion: A case study of first year electrical and electronics engineering students. Journal of Education and Practice, 6(10), 143-148. 
Thorley, M. (2014). Graduate meets employer - a model for embedding industry professional involvement in the development and assessment of student portfolios. Journal of Music, Technology \& Education, 7(3), 325-339. doi:10.1386/jmte.7.3.325_1

Thunborg, C., Bron, A., \& Edström, E. (2013). Motives, commitment and student identity in higher education - experiences of non-traditional students in Sweden. Studies in the Education of Adults, 45(2), 177.

Treleaven, L., \& Voola, R. (2008). Integrating the development of graduate attributes through constructive alignment. Journal of Marketing Education, 30(2), 160-173. doi:10.1177/0273475308319352

von Konsky, B.R., \& Oliver, B. (2012). The iPortfolio: Measuring uptake and effective use of an institutional electronic portfolio in higher education. Australasian Journal of Educational Technology, 28(1), 67-90.

Whatley, J. (2012). Evaluation of a team project based learning module for developing employability skills. Issues in Informing Science and Information Technology, 9, 75-92.

Yang, P., \& Ying Lin, X. (2014). Employability as a new mission? Organizational changes in Chinese vocational colleges. Chinese Education and Society, 47(5), 8-26. doi:10.2753/CED10611932470501 